\title{
The Effect of Biochar Mixed with Compost on Heavy Metal Concentrations in a Greenhouse Experiment and on Folsomia Candida and Eisenia Andrei in Laboratory Conditions
}

\author{
ELENA GOLDAN ${ }^{1}$, VALENTIN NEDEFF ${ }^{1,2 *}$, NARCIS BARSAN ${ }^{1}$, EMILIAN MOSNEGUTU ${ }^{1}$, ANDREI VICTOR SANDU ${ }^{3,4}$, \\ MIRELA PANAINTE ${ }^{1}$ \\ 'Vasile Alecsandri University of Bacau, Faculty of Engineering, 157 Marasesti Str., 600115 Bacau, Romania \\ ${ }^{2}$ Gheorghe Ionescu Sisesti Academy of Agricultural an Forest Sciences, 61 Marasti Str., 011464, Bucharest, Romania
}

\begin{abstract}
Organic wastes treated, used on agricultural land, can replace inorganic fertilizers, due to physical and chemical properties that improve soil and crop quality on long-term. In this study, was used biochar produced from sewage sludge, compost obtained from cattle manure, and mixtures made from biochar-compost in different concentration, at 5 tha and 30 t/ha, application rates. The aim of the study is to determine the influence of this organic wastes on the heavy metals bioavailability in greenhouse conditions and on Folsomia candida and Eisenia Andrei, used as testorganisms under laboratory conditions. Compared to control variants, the use of biochar mixed with compost in different concentration at $5 \mathrm{t} / \mathrm{ha}$ and $30 \mathrm{t} / \mathrm{ha}$, application rates, in a greenhouse experiment did not significantly affect the concentrations of heavy metals $(\mathrm{Cu}, \mathrm{Cd}, \mathrm{Zn}$ and $\mathrm{Pb})$. Reproduction of collembolans has not been influenced by increasing application rate of the mixtures, and by concentrations of biochar or compost. The earthworms recorded weight losses, only in the experimental treatments with sewage sludge biochar used in different concentrations, at both application rates.
\end{abstract}

Keywords: biochar, compost, heavy metals, toxicity tests

The use of organic wastes on agricultural lands is very important, not only because it reduces the volume of landfilled waste, contributing to the policy on waste disposal and achieving recycling targets in Europe, but also because this wastes can improves soil fertility [1]. Organic wastes which can be used in agriculture, can be treated by various methods, so as to retain a large quantity of nutrients and to increase their agronomic value in while environmental impact is minimum [2].

The use of biochar mixed with compost as a soil amendment, can have an excellent agronomic value compared to the use of biochar alone, because its influences soil properties such as physical structure, fertility, microbial activity, crop growth, and bioavailability of nutrients and toxic compounds [3,4]. Though sewage sludge is a valuable source of phosphorus, nitrogen, micronutrients and organic matter that can positively influence soil properties and plant productivity. The heavy metal content may be a constraint for application of sewage or sludge for soil remediation [5-9].

To evaluate the environmental impact of the use of sewage sludge biochar is essential to know the solubility, mobility of heavy metals and how heavy metals interact with the soil and it is also important to determine the toxicity of biochar to different organisms/plants standard $[9,10]$. Are few studies where sewage sludge biochar or cattle manure compost was tested with organisms and plants standard in laboratory conditions. For example, the authors $[11,12]$, determined the effects of the sewage sludge biochar on differentstandard test plants. Collembolans and earthworms are used in standardized eco-toxicological tests because of its large scale distribution in different soil types, high sensitivity, locomotor capacity, role in organic matter decomposition, and its behaviour can be measured, e.g. mortality rate and reproduction rate [12-18].
In this study was used sewage sludge biochar mixed with cattle manure compost in different concentrations, at $5 \mathrm{t} / \mathrm{ha}$ and $30 \mathrm{t} / \mathrm{ha}$ application rates, with the aim to determine the influence of this organic wastes on heavy metals concentration in a greenhouse experiment. Also was determined the influence of sewage sludge biochar mixed with cattle manure compost, using the same concentrations and application rates, on the testorganisms, Folsomia candida and Eisenia Andrei, in laboratory conditions.

\section{Experimental part}

Organic waste treated

The NovoCarbo Company from Germany produced the sewage sludge biochar by the slow pyrolysis process at $500^{\circ} \mathrm{C}$, and 15 minutes, retention time.

To obtain the compost, the cattle manure pile was covered with a layer of soil and left in natural conditions, without to turning the pile for 2 years. The passive composting method in static pile was also used by the authors [20], but they covered the pile with a polypropylene membrane for 168 days.

\section{Application rates and concentrations of organic wastes treated}

For the greenhouse experiment and laboratory toxicity tests with Folsomia candida and Eisenia Andrei, the compost (M) in concentrations by $0,10,20,30,40,50,60$, $70,80,90$ and $100 \%$ was mixed with biochar in concentrations by $100,90,80,70,60,50,40,30,20,10$ and $0 \%$.

In this study were used biochar mixed with compost for a small application rate, by 5 t/ha and for a higher application rate by $30 \mathrm{t} / \mathrm{ha}$, for example, and authors [13, 21-24] have used different application rates in their studies. The name of the experimental treatments was established 
by the compost $(\mathrm{M})$ and biochar $(\mathrm{B})$ concentrations used in the mixtures at each application rate: $C$ (control), $\mathrm{MO}$ B100, M10-B90, M20-B80, M30-B70, M40-B60, M50-B50, M60-B40, M70-B30, M80-B20, M90-B10, M100-B0.

\section{The experiment in greenhouse conditions}

The soil was collected in July 2016 from an area that has not been cultivated by minimum 5 years, from Bacau county, Romania, coordinated $46^{\circ} 23^{\prime} 00.2^{\prime \prime} \mathrm{N} 27^{\circ} 12^{\prime} 34.0^{\prime \prime} \mathrm{E}$.

\section{Experimental treatments for greenhouse experiment}

For each biochar-compost mixture, was used $9 \mathrm{~kg}$ of soil and the amounts of compost and biochar according to the concentrations of the mixtures and application rate, resulting 6 replicates. In the greenhouse experiment, autumn barley was chosen as study plant for a period of 90 days. For soil sampling, a metal cylinder with a diameter of $4 \mathrm{~cm}$ was used. From this greenhouse experiment, other results were presented in the article [25].

\section{The bioavailability of heavy metals}

To determine the bioavailability of heavy metals, each extract were made from $10 \mathrm{~g}$ of soil sample and $50 \mathrm{~mL}$ of demineralized water, and the sample was stirred at 120 rpm for 2 hours. The extracts were filtered twice, after which $1 \%$ nitric acid was added. This method of measuring the concentrations of heavy metals has been used in other studies [26, 27]. The heavy metal concentrations ( $\mathrm{Cu}, \mathrm{Cd}$, $\mathrm{Pb}$ and $\mathrm{Zn}$ ) were measured using the Varian $\mathrm{AA} 240 \mathrm{FS}$ spectrophotometer, by the atomic flame absorption spectrophotometric method.

\section{Toxicity tests in laboratory conditions}

Toxicity tests were performed for the same application rates, with the same concentrations used in the greenhouse experiment, but at a lower laboratory scale, using artificial soil obtained in laboratory by mixing homogeneously $10 \%$ sphagnum peat dried, $20 \%$ kaolin clay, $70 \%$ quartz sand, particle size $0.063-0.0355 \mathrm{~mm}$. The artificial soil used in the toxicity tests was performed following the method described in $[28,29]$. The composition of the artificial soil has been optimized so as to obtain a standardized environment that can be used to produce reproducible and comparable data [30]. The mixtures sewage sludge biochar - cattle manure compost, was noted just like those used in the greenhouse experiment.

\section{Experimental treatments for toxicity tests}

For each biochar-compost treatment, a homogeneous mixture was made from artificial soil, compost-biochar quantities according to the concentrations and application rate, in which was added $1 \%$ calcium carbonate to adjust the $\mathrm{pH}$ of the artificial soil, and distilled water to adjust the mixture at 40\% WHC (water holding capacity) [31].

\section{Testing biochar-compost mixtures with Folsomia candida}

Each experimental treatment was performed in 6 replicates, and in each plastic container with volume by $110 \mathrm{~mL}$ was added $25 \mathrm{~g}$ from experimental treatment and ten collembolans aged 10-12 days [32]. The toxicity test was performed according to the method described in [33], for 28 days under laboratory conditions at a temperature of $20-22^{\circ} \mathrm{C}$ in the dark. During the test, dryyeast was added as food at the start of the test and after 14 days and each plastic container was airy two times per week. At the end of the test, the content of each plastic container were placed in a $500 \mathrm{~mL}$ volumetric flask, added water and a few drops of ink, and taken pictures, which were then inserted into the Image] program, the free version, to determine the number of adults and juveniles [30,34].

\section{Testing biochar-compost mixtures with Eisenia Andrei}

The number of earthworms was reduced to 5 , instead of 10, for example, the authors [35], reduced the number of earthworms to 6 . For this test, three replicates were used for each experimental treatment [36], and plastic containers with a volume by $250 \mathrm{~mL}$, which at the top had small holes to allow aeration. In each plastic container was added $123 \mathrm{~g}$ from experimental treatment and five individuals were weighed and added, and no food was used throughout the test. The experimental treatments were kept at $20^{\circ} \mathrm{C}$ for 14 days and at the end of the test, was determined the number of earthworms and the biomass earthworms [37]. The change in biomass of earthworms, expressed as a percentage, was calculated according to the formula presented by the authors [38].

\section{Results and discussions}

Influence of biochar-compost mixtures on heavy metal concentrations

The bioavailable fraction of a heavy metal in the soil has an important role in its accumulation in plants [27]. Many studies have show $n$ that the absorption of heavy metals by plants is positively associated with the bioavailable concentration of heavy metals in the soil [27]. The main elements of interest are: arsenic, cadmium, copper, chromium, mercury, nickel, molybdenum, zinc and cobalt $[39,40]$.

\section{Concentration of cadmium}

Figure 1 shows that the biochar produced a slight increase in cadmium concentration when was applied in $100 \%$ concentrations at 5 t/ha and at $30 \mathrm{t} / \mathrm{ha}$ application rate. In the rest of experimental treatments, M10-B90 until M100-B0, the concentrations of cadmium recorded decreasing values, in particular at 30 t/ha, application rate, concentration of cadmium was lower than values from control variants.

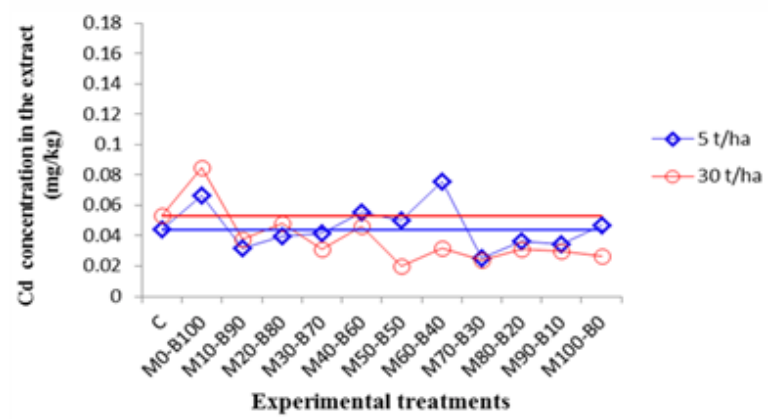

Fig. 1. Effect of biochar mixed with compost on cadmium concentration

In another study, where the authors used compost from cattle manure, chromium, nickel, lead and cadmium concentrations in the soil were not significantly higher than values recorded in soil control [41]. It has been noticed that sewage sludge biochar reduced the concentrations of arsenic, lead, copper and zinc, when application rate increased, while the cadmium concentration recorded similar values with those from the control variant [40].

\section{Concentration of zinc}

The experimental treatments used at $30 \mathrm{t} / \mathrm{ha}$ application rate, caused an increase in zinc concentration only when the sewage sludge biochar was used at 100\% concentration. Was an increase in zinc concentration, at 5 tha application rate, especially in experimental treatments 
where the amount of compost increased, the values being higher than those determined for the application rate of 30 tha, as show $n$ in figure 2.

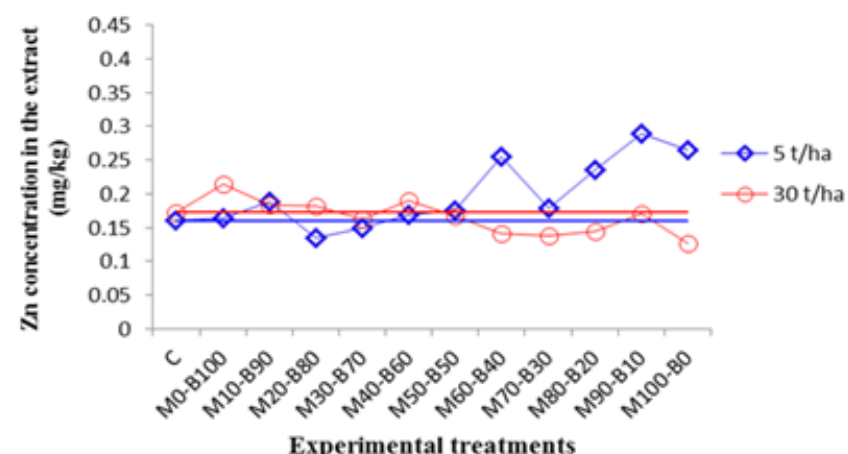

Fig. 2. Effect of biochar mixed with compost on zinc concentration

Recent studies have shown that the biochar has the ability to immobilize heavy metals in the soil due to its porous structure, active functional groups and high cation exchange capacity $[42,43]$. The biochar reduces the bioavailability of heavy metals in soils and can suppress the absorption and translocation of these contaminants to plants [44].

\section{Concentration of copper}

Figure 3 shows that for both application rates, the concentration of copper from experimental treatment with $100 \%$ biochar and 0\% compost (M0-B100), was similar with the values measured in the control variants. The cattle manure compost caused an increase of copper concentration, when the quantity of compost increased in the experimental variants, at $5 \mathrm{t} / \mathrm{ha}$ and at $30 \mathrm{t} / \mathrm{ha}$, application rate.

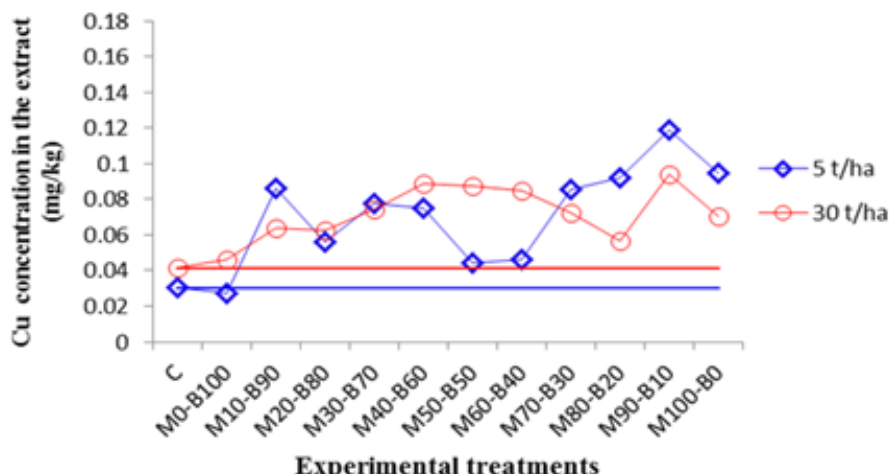

Fig. 3. Effect of biochar mixed with compost on copper concentration

The amount of heavy metals ( $\mathrm{Cu}, \mathrm{Zn}, \mathrm{Cr}, \mathrm{Mn}$ and $\mathrm{Pb}$ ) from another study, measured by digestion method, increased as a result of increasing the amount of cattle manure compost in the samples, but the measured values did not exceed the limits imposed by the legislation [45].

\section{Concentration of lead}

Sewage sludge biochar mixed with cattle manure compost in different concentrations, did not significantly affect the lead concentration, only the experimental treatment with $0 \%$ compost $-100 \%$ biochar (M0-B100), used at 5 t/ha and 30 t/application rates, increased the lead concentration, as shown in the figure 4.

Other studies shows that after application of sewage sludge biochar, the lead and copper values have increased and cadmium and zinc have lower values than those in the control variant [26]. The zinc, copper, and lead concentrations determined by the digestion method,

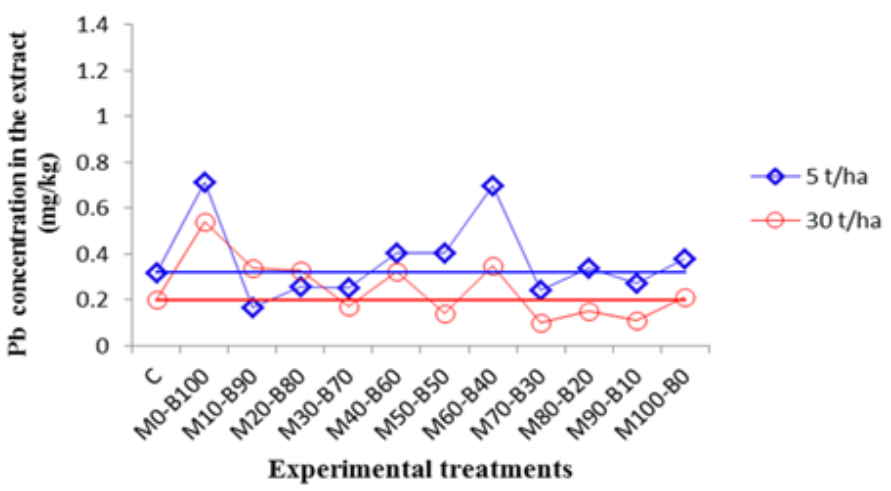

Fig. 4. Effect of biochar mixed with compost on lead concentration

increased in samples amended with sewage sludge biochar [46]. It has been determined that utilization of sewage sludge biochar reduced the concentrations of $\mathrm{Fe}$, $\mathrm{Pb}, \mathrm{Cu}, \mathrm{Zn}, \mathrm{Cr}$ and As measured in the extracts, depending on application rates [23].

Influence of biocharmixed with compost on test organisms Influence of biochar mixed with compost on Folsomia candida

The toxicity test is considered valid if at least 7 adult collembolans, from 10 added at the beginning of the text, are found at the end of the test in each test variant [33]. After 28 days from the start of the toxicity test, it is noted in Figure 5 that the number of adults was reduced to nearly 8 in each test variant. The use at $5 \mathrm{t} / \mathrm{ha}$ and $30 \mathrm{t} / \mathrm{ha}$, application rates, of organic wastes treated in different concentration, did not significantly affect the number of adults recorded at the end of the test, based on the results obtained in the control variants.

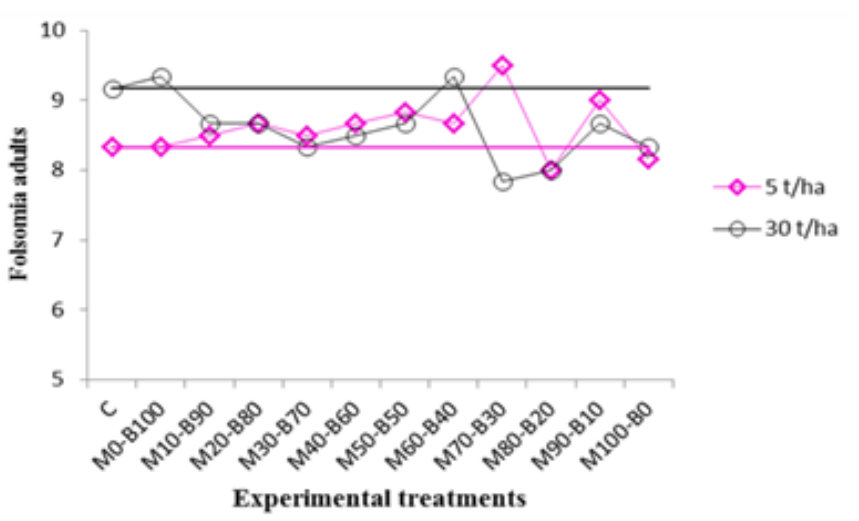

Fig. 5.Effect of biochar mixed with compost on adult collembolans

Figure 6 shows the number of juveniles determined at the end of the toxicity test, and the results show that number of juveniles reached a maximum at $5 \mathrm{t} / \mathrm{ha}$, in

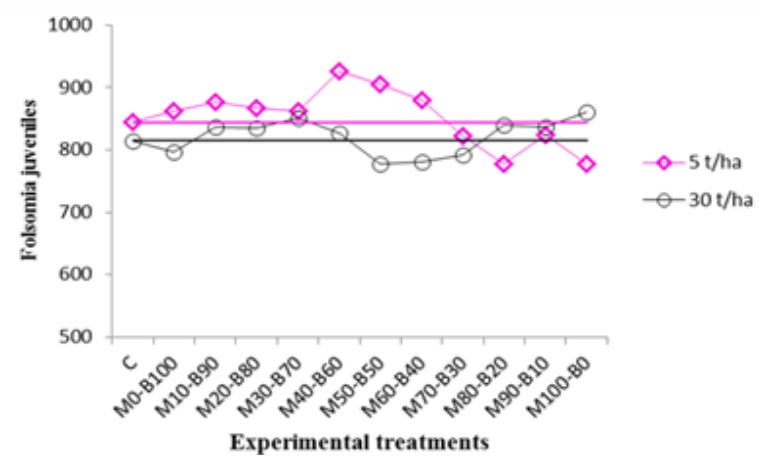

Fig. 6.Effect of biochar mixed with compost on juveniles 
experimental treatments with $60 \%$ compost - $40 \%$ biochar (M60-B40) and 50\% compost - 50\% biochar (M50-B50). The number of juveniles recorded at $30 \mathrm{t} / \mathrm{ha}$, application rate, did not exceed the number of juveniles from $5 \mathrm{t} / \mathrm{ha}$.

In the literature only the authors [31], tested the sewage sludge biochar with testorganisms, and they observed that biochar had a low effect on the tw o test species, Folsomia candida and Enchytreus crypticus.

\section{Influence of biochar mixed with compost on earthworms}

During the 14 days of testing, the number of earthworms has diminished, especially in the case of experimental treatments with a big concentration of biochar at $5 \mathrm{t} / \mathrm{ha}$ and 30 tha, application rate. In contrast, in the case of experimental treatment with a high quantity of compost, is presented in figure 7 that the number of earthworms was relatively the same as the number of earthworms initiallyadded.

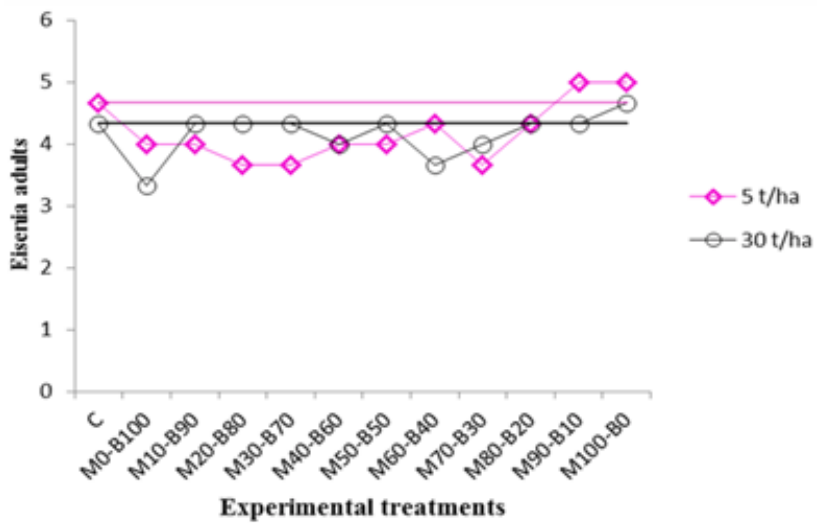

Fig. 7. Effect of biochar mixed with compost on earthworms

The sewage sludge biochar used in different concentration in the experimental treatments, produced the most significant decrease of the earthworms biomass, but the compost, used alone in experimental treatments, increased the earthworms biomass by $3 \%$ to 5 tha, and $4 \%$ to 30 t/ha, application rate, as shown in figure 8 .

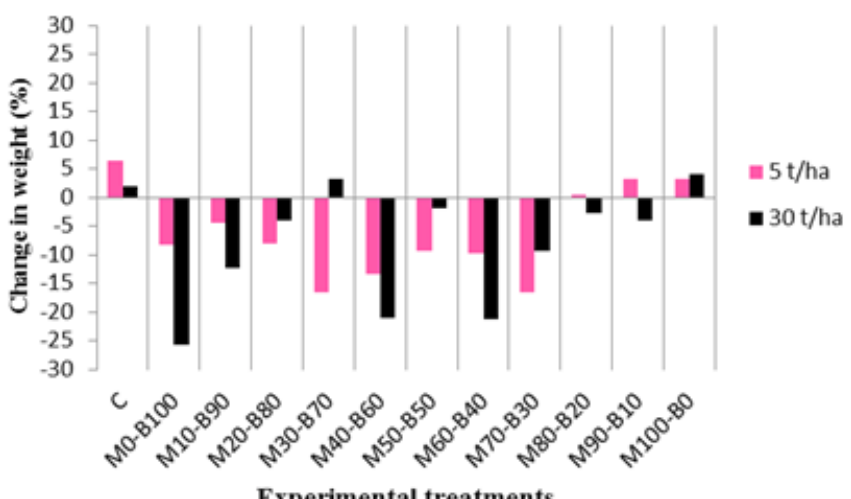

Fig. 8. Effects of biochar mixed with compost on earthworms biomass

In the results presented by [47], the total density and total biomass of earthworms Eisenia foetida increased in the same time with concentration of cattle manure compost from the samples, and density and total biomass of earthworms P.guillelmi also increased in samples with cattle manure compost.

\section{Conclusions}

The biochar used at $100 \%$ concentration in experimental treatments at 5 t/ha and 30 t/ha application rates, increased $\mathrm{Cd}$ and $\mathrm{Pb}$ concentrations, while $\mathrm{Zn}$ and Cu concentrations recorded high values in experimental treatments with a big quantity of compost.

Different concentrations and application rates of biochar and compost used in the experimental treatments had an insignificant effect on the collembolans reproduction.

Following the toxicity test with Eisenia Andrei, the biochar had a negative effect on the mortality and biomass of the earthworms, reducing the earthworms biomass by $25 \%$ in the experimental treatment with only biochar at 30 t/ha, application rate.

Acknowledgements: This study was possible thanks to the NovoCarbo Company that offered free the sewage sludge biochar.

\section{References}

1.ALVARENG, P., MOURINHA, C., FARTO, M., PALMA, P., SENGO, J., MORAIS, M.C., CUNHA-QUEDA, C., Ecotoxicology and Environmental Safety, 126, 2016, p. 102.

2.CASE, S.D.C., OELOFSE, M., HOU, Y., OENEMA, O., JENSEN, L.S., Agricultural Systems, 151, 2017, p. 84.

3.BIELSKÁ, L., KAH, M., SIGMUND, G., HOFMANN, T., HOSS, S., Science of the Total Environment, 595, 2017, p. 132.

4.SOJA, G., WIMMER, B., ROSNER, F., FABER, F., DERSCH, G., CHAMIERA, J., PARDELLER, G., AMEUR, D., KEIBLINGER, K., ZEHETNER, F., Applied Geochemistry, 88, 2018, p. 40.

5.CHITIMUS, A.D., RADU, C., NEDEFF, V., MOSNEGUTU, E.F., BARSAN, N., Scientific Study $\&$ Research, Chemistry \& Chemical Engineering, Biotechnology, Food Industry, 17, no. 4, 2016, p. 381.

6.CHITIMUS, A.D., COCHIORCA, A., NEDEFF, V., BARSAN, N., MUSCALU PLESCAN, O.M., Studies and research on phragmites australis' (common reed) absorption capacity of heavy metals from the soil in Roman City, Romania, Proceeding of the International Multidisciplinary Scientific GeoConference Surveying Geology and Mining Ecology Management, SGEM, 18, 2018, pp. 671-678.

7.CHITIMUS, A.D., NEDEFF, V., MOSNEGUTU, E.F., PANAINTE, M., Environmental Engineering and ManagementJ ournal, 11, no. 12, 2012, p. 2161.

8.MUSCALU PLESCAN, O.M., NEDEFF, V., CHITIMUS, A.D., SANDU, I.G., PARTAL, E., MOSNEGUTU, E., SANDU, I., RUSU, I.D., Rev.Chim.(Bucharest), 69, no. 11, 2018, p. 3106.

9.RADU, C., NEDEFF, V., CHITIMUS, A.D., J ournal of Engineering Studies and Research, 19, no. 2, 2013, p. 89.

10.AGRAFIOTI E., BOURAS G., KALDERIS D., DIAMADOPOULOS E., J ournal of Analytical and Applied Pyrolysis, 101, 2013, p. 72.

11.ZIELINSKA, A., OLESZCZUK, P., Biomass and Bioenergy, 75, 2015, p. 235.

12.MARKS, E.A.N., ALCANIZ, J.M., DOMENE, X., Unintended effects of biochars on short-term plant growth in a calcareous soil, Plant and Soil, 385, no. 1-2, 2014, p. 87.

13.GONZAGA, M.I.S., MACKOWIAK, C.L., COMERFORD, N.B., DA VEIGA MOLINE, E. F., SHIRLEY, J.P., GUIMARAES, D.V., Soil and Tillage Research, 165, 2017, p. 59.

14.ALVES, P.R.L., CARDOSO, E.J.B.N., Overview of the Standard Methods for Soil Ecotoxicology Testing, Invertebrates - Experimental Models in Toxicity Screening, 2016, available on-line at https:// www.intechopen.com/books/invertebrates-experimental-models-intoxicity-screening/overview-of-the-standard-methods-for-soilecotoxicology-testing.

15.LUO, W., VERWEIJ R.A., VAN GESTEL C.A., Journal of Hazardous Materials, 280, 2014, p. 524.

16.REN, X., ZENG, G., TANG, L., WANG, J., WAN, J., FENG, H., SONG, B., HUANG, C., TANG, X., Soil Biology and Biochemistry, 116, 2018, p. 70.

17.PINO, M.R., VAL, J., MAINAR, A.M., ZURIAGA, E., ESPANOL, C., LANGA, E., Science of the Total Environment, 518-519, 2015, p. 225. 18.COULIBALY, S.S., EDOUKOU, F.E., KOUASSI, K.I., BARSAN, N., NEDEFF, V., BI ZORO, I.A., Helyon, 2018, 4, no. 12, p. e01104. 
19.0MOURI, Z., HAWARI, J., FOURNIER, M., ROBIDOUX, P.Y., Ecotoxicology and Environmental Safety, 147, 2018, p. 1.

20.BRITO, L.M., MOURAO, I., COUTINHO, J., SMITH, S.R., Waste Management, 32, no. 7, 2012, p. 1332.

21.PANEQUE, M., DE LA ROSA, J.M., FRANCO-NAVARRO, J.D., COLMENERO-FLORES, J.M., KNICKER, H., Catena, 147, 2016, p. 280. 22.KHAN, S., WANG, N., REID, B.J ., FREDDO, A., CA,I C., Environmental Pollution, 175, 2013, p. 64.

23.FANG, S., TSANG, D.C.W., ZHOU, F., ZHANG, W., QIU, R., Chemosphere, 149, 2016, p. 263.

24.LEE, J., HortTechnology, 22, no. 6, 2012. p. 798.

25.GOLDAN, E., NEDEFF, V., SANDU, I.G., MOSNEGUTU, E., PANAINTE, M., Rev.Chim.(Bucharest), 70, no. 1 2019, p. 169.

26.MENDEZ, A., PAZ-FERREIRO, G.J., GASCO, G., Chemosphere, 89, no. 11, 2012, p. 1354.

27.XIAO, L., GUAN, D., PEART, M.R., CHEN, Y., LI, Q., DAI, J ., Chemosphere, 185, 2017, p. 868.

28.LI, D., HOCKADAY, W.C., MASIELLO, C.A., ALVAREZ, P.J .J., Soil Biology and Biochemistry, 43, no. 8, 2011, p. 1732.

29.PIVATO, A., LAVAGNOLO, M.C., MANACHINI, B., RAGA, R. BEGGIO, G., VANIN, S., Journal of Material Cycles and Waste Management, 20, 2018, p. 552.

30.VASIEKOVA, J., VÁÒA, M., KOMPRDOVA, K., HOFMAN, J., Ecotoxicology and Environmental Safety, 2015, 114. p. 38.

31.MARKS, E.A.N., MATTANA, S., ALCANIZA, J.M., DOMENE, X., European Journal of Soil Biology, 60, 2014, p. 104.

32.ZORTEA, T., ZORTEA, T., SEGAT, J.C., MACCARI, A.P., SOUSA, J.P., DA SILVA, A.S., BARETTA, D., Chemosphere, 173, 2017, p. 460.

33.DOMENE, X., ENDERS, A., HANLEY, K., LEHMANN, J., Science of the Total Environment, 512-513, 2015, p. 552.

34.BIELSKA, L., SKULCOVA, L., NEUWIRTHOVA, N., CORNELISSEN, G., HALE, S.E., Science of the Total Environment, 624, 2018, p. 78.
35.DOMENE, X., SOLA, L., RAMIREZ, W., ALCAÑIZ, J.M., ANDRES, P., Waste Management, 31, no. 3, 2011, p. 512.

36.OLGA, S., FINDORAKOVA, L., HANCULAK, J., FEDOROVA, E. TOMISLAV, S., Terrestrial Eco-Toxicological Tests as Screening Tool to Assess Soil Contamination in Krompachy Area, IOP Conference Series: Earth and Environmental Science, 44, 2016, available on-line at: https:/ /iopscience.iop.org/article/10.1088/1755-1315/44/5/052041/pdf

37.KACZYNSKA, A., CYCON, M., Pestycydy, 1-2, 2004, p. 5.

38.LIESCH, A.M., WEYERS, S.L., GASKIN, J.W., DAS, K.C., Annals of Environmental Science, 4, 2010, p. 1.

39.CLEVERSON VITORIO ANDREOLI, M.V.S., FERNANDES F., RONTELTAP M., Sludge Treatment and Disposal, Vol. 6, IWA Publishing, 2007.

40.WAQAS, M., KHAN, S., QING, H., REID, B.J., CHAO, C., Chemosphere, 105, 2014, p. 53.

41.GIL, M.V., CARBALLO, M.T., CALVO, L.F., Waste Management, 28, no. 8, 2008, p. 1432.

42.ZHANG, R.-H., LI, Z.-G., LIU, X.-D., WANG, B.-C., ZHOU, G.-L., HUANG, X.-X., LIN, C.-F. WANG, A.-H., BROOKS, M., Ecological Engineering, 98, 2017, p. 183.

43.MENG, J.,TAO, M., WANG, L., LIU, X., XU, J., Science of the Total Environment, 633, 2018, p. 300.

44.ZHANG, Y., CHEN, T., LIAO, Y., REID, B.J ., CHI, H., HOU, Y., CAI, C., Environmental Pollution, 216, 2016, p. 819.

45.J AYASINGHE, G.Y., ARACHCHI, I.D.L., TOKASHIKI, Y., Resources, Conservation and Recycling, 54, no. 12, 2010. p. 1412.

46.GWENZI, W., MUZAVA, M., MAPANDA, F., TAURO, T.P., J ournal of Integrative Agriculture, 15, no. 6, 2016, p. 1395.

47.GUO, L., WU, G., LI, Y., LI, C., LIU, W., MENG, J., LI, H., YU, X., JIANG, G., Soil and Tillage Research, 156, 2016, p. 140.

$\overline{\text { Manuscript received: } 17.09 .2018}$ 